\title{
Studies on the Light Controlling Flower Initiation of Pharbitis Nil. VII : Light-break
}

\author{
by Atsushi TакIмото* and Katsuhiko IKeDA*
}

Received March 4, 1960

It is well known that a short interval of light (light-break) given during the dark period inhibits flower initiation of short day plants $\left.{ }^{1,2}\right)$. Generally, the lightbreak is most effective near the middle of the daily dark period. When the lightbreak is given during a long dark period of 36-72 hours' duration, it is effective only during the first 6 to 10 hours of darkness or towards the end of the dark period ${ }^{3-7}$ ).

In a preliminary report, however, it was suggested that the light-break towards the end of the long dark period had little effect on the flowering response of Pharbitis seedlings ${ }^{8}$ ).

Extensive studies have been made by Borthwick et al. on the action spectrum for the light-break, and it was found that red light is the most effective ${ }^{9,10}$ ). Furthermore, it was found that the inhibitory effect of red radiant energy was almost completely reversed by a subsequent irradiation with far-red ${ }^{11,12}$ ).

In Pharbitis, too, red light is the most effective portion of the spectrum for the light-break, but recently Nakayama reported that the inhibitory effect of the red can not be reversed by a subsequent irradiation with far-red in Pharbitis seedlings. Furthermore far-red radiant energy is also effective for the light-break when given to the plant during the initial hours of dark period ${ }^{13}$ ). Thus, Pharbitis plants appear to differ from other short day plants in their response to the light-break.

In the present experiments, the light-break with red or far-red radiant energy was given to Pharbitis seedlings at various times during the long dark period, and Nakayama's experiments in which the antagonism between red and far-red was not observed were examined in detail.

\section{Material and Methods}

Material used was seedlings of Pharbitis Nil, strain "Violet". The experimental methods employed were similar to those described in a previous paper $\left.{ }^{14}\right)$. Red radiant energy was obtained from pink fluorescent lamps with a filter of 2 layers of red cellophane. Far-red was obtained from incandescent lamps with a filter composed of $5 \mathrm{~cm}$. water, 2 layers of blue and 2 layers of red cellophane.

\section{Experiments and Results}

Experiment 1. One group of plants were irradiated for 2 minutes with red radiant energy of $1.5 \mathrm{kiloerg} / \mathrm{cm} .{ }^{2} / \mathrm{sec}$. at various times during a 48 -hour dark period. Another group was treated in the same way as the first except that 5 minutes of far-red followed the 2-minute irradiation with red.

Results are summarized in Fig. 1. Light-break with red was effective only 8 to 12 hours after the beginning of the dark period. The red irradiation had no effect

* Laboratory of Applied Botany, Faculty of Agriculture, Kyoto University, Kyoto, Japan. 


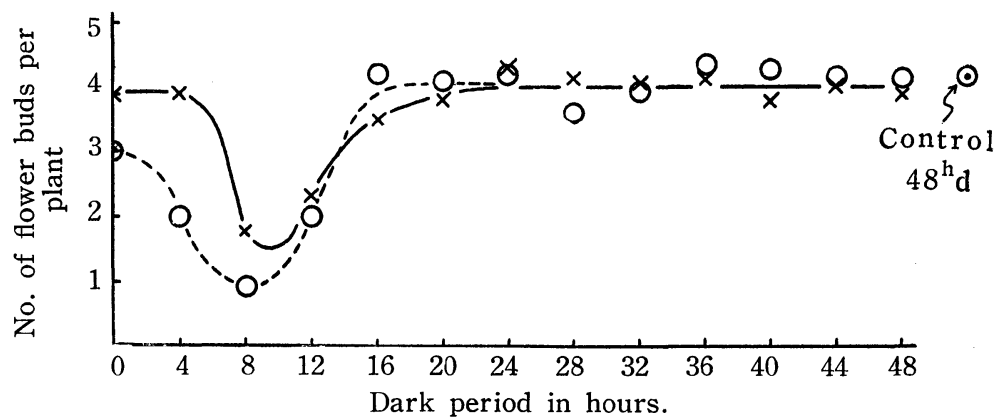

Fig. 1. Flowering response of Pharbitis seedlings subjected to 2-minute red $\left(1500 \mathrm{erg} / \mathrm{cm}^{2} / \mathrm{sec}\right.$.) and that followed by 5 minute far-red $\left(15 \mathrm{kiloerg} / \mathrm{cm} \cdot{ }^{2} / \mathrm{sec}\right.$.) at various times during a 48-hour dark period.

Solid line: red

Broken line: red followed by far-red

(Treated on March 17 and dissected on April 1, 1959)

when given towards the end of the dark period. A far-red irradiation immediately following the red did not remove the inhibitory effect of the red at any time during the dark period, but it intensified the flower-inhibitory effect during the first 12 hours. This result agrees with the findings of Nakayama ${ }^{13}$ ).

Experiment 2. One group of the plants were irradiated for 5 minutes with farred radiant energy of $15 \mathrm{kiloerg} / \mathrm{cm} .{ }^{2} / \mathrm{sec}$. at various times during the 48 -hour dark period. Another group was treated in the same way, but 2 minutes of red radiant energy followed the 5-minute exposure to far-red.

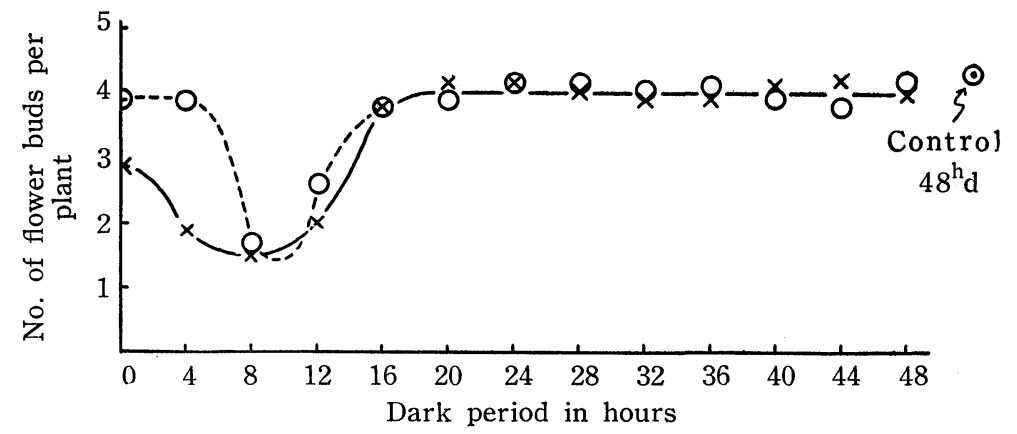

Fig. 2. Flowering response of Pharbitis seedlings subjected to 5 -minute far.red (15 kiloerg $/ \mathrm{cm} .2 / \mathrm{sec}$.) and that followed by 2 -minute red $\left(1500 \mathrm{erg} / \mathrm{cm}^{2} / \mathrm{sec}\right.$.) at various times during a 48 hour dark period.

Solid line: far-red

Broken line: far-red followed by red (Treated on March 18 and dissected on April 3, 1959)

As shown in Fig. 2, far-red given during the first hours of the dark period inhibits flower initiation. Maximum inhibition was observed after 8 hours of the darkness. Red radiant energy following the far-red irradiation completely reversed the flower-inhibitory effect of far-red at the beginning or the 4th hour of the dark period, but had little effect at any other times. 
Experiments 1 and 2 were repeated several times with dark periods of 16,24 or 32 hours. In all experiments, the light-break with red radiant energy was effective only after 8 to 12 hours of darkness and far-red acted like red only during the first 12 hours. Far-red following a red irradiation, and red following a far-red irradiation showed similar effects in all experiments.

Experiment 3. One minute of red radiant energy of $1500 \mathrm{erg} / \mathrm{cm} .{ }^{2} / \mathrm{sec}$. was given in the middle of a 16 -hour dark period, and far-red irradiations (15 kiloerg $/ \mathrm{cm} .{ }^{2} / \mathrm{sec}$.) of various durations were given following the red irradiation. Results are shown in Table 1.

Table 1. Flowering response of Pharbitis seedlings irradiated for 1 minute with red radiant energy of $1500 \mathrm{erg} / \mathrm{cm}^{2} / \mathrm{sec}$. followed by various durations of far-red irradiation ( $15 \mathrm{kiloerg} / \mathrm{cm}^{2} . / \mathrm{sec}$.) in the middle of a 16 -hour dark period.

(Treated on March 28 and dissected on April 16, 1959)

\begin{tabular}{c|ccc}
$\begin{array}{c}\text { Duration of far-red } \\
\text { irradiation }\end{array}$ & $\begin{array}{c}\text { No. of plants } \\
\text { dissected }\end{array}$ & $\begin{array}{c}\% \text { of plants } \\
\text { with flower buds }\end{array}$ & $\begin{array}{c}\text { No. of flower buds } \\
\text { per plant }\end{array}$ \\
\hline Dark control & 38 & 100 & 3.1 \\
0 & 37 & 51.3 & 0.6 \\
$1^{\prime \prime}$ & 37 & 62.2 & 0.8 \\
$5^{\prime \prime}$ & 38 & 50.0 & 0.8 \\
$10^{\prime \prime}$ & 36 & 58.3 & 0.8 \\
$30^{\prime \prime}$ & 37 & 16.2 & 0.2 \\
$1^{\prime}$ & 37 & 29.8 & 0.3 \\
$2^{\prime}$ & 37 & 2.7 & 0.0 \\
$5^{\prime}$ & 37 & 0 & 0
\end{tabular}

A far-red irradiation for 1-10 seconds had no significant effect on flowering response, but irradiations of 30 seconds to 5 minutes intensified the flower-inhibitory effect.

Experiment 4. One minute of red and 1 minute of far-red were given alternately in the middle of the 16-hour dark period. As shown in Table 2, it appears that the inhibitory effect of the red irradiation is not reversed by a subsequent irradiation

Table 2. Flowering response of Pharbitis seedlings exposed alternately to 1-minute red and 1-minute far-red irradiation in the middle of a 16-hour dark period.

$\mathrm{R}$ : red radiant energy of $1500 \mathrm{erg} / \mathrm{cm}^{2} / \mathrm{sec}$.

FR: far-red radiant energy of $15 \mathrm{kiloerg} / \mathrm{cm} .{ }^{2} / \mathrm{sec}$.

(Treated on March 10 and dissected on March 27, 1959)

\begin{tabular}{l|ccc}
\multicolumn{1}{c|}{ Treatment } & $\begin{array}{c}\text { No. of plants } \\
\text { dissected }\end{array}$ & $\begin{array}{c}\text { \% of plants } \\
\text { with flower buds }\end{array}$ & $\begin{array}{c}\text { No. of flower buds } \\
\text { per plant }\end{array}$ \\
\hline Dark control & 37 & 100 & 4.1 \\
$R$ & 37 & 91.9 & 2.0 \\
FR & 37 & 86.5 & 2.1 \\
$R \rightarrow F R$ & 36 & 52.8 & 0.8 \\
$R \rightarrow F R \rightarrow R$ & 31 & 67.8 & 1.2 \\
$R \rightarrow F R \rightarrow R \rightarrow F R$ & 35 & 0 & 0 \\
$R \rightarrow F R \rightarrow R \rightarrow F R \rightarrow R$ & 37 & 27.0 & 0.3 \\
$R \rightarrow F R \rightarrow R \rightarrow F R \rightarrow R \rightarrow F R$ & 37 & 0 & 0
\end{tabular}


with far-red, although the inhibitory effect of far-red is partially reversed by a subsequent exposure to red. This result does not agree with the results obtained with Xanthium, Biloxi soybean, etc., in which the inhibitory effect of red radiant energy is reversed by a subsequent irradiation with far-red.

Experiment 5. One minute of red and 10 seconds of far-red, or 2 minutes of far-red and 20 seconds of red were given alternately in the middle of a 16-hour dark period. Results are presented in Table 3 .

Table 3. Flowering response of Pharbitis seedlings exposed alternately to 1-minute red and 10 -second far-red irradiation or 2-minute far-red and 20-second red irradiation in the middle of a 16 -hour dark period.

(Treated on April 6, and dissected on April 25, 1959)

\begin{tabular}{|c|c|c|c|c|}
\hline Group & Treatment & $\begin{array}{l}\text { No. of plants } \\
\text { dissected }\end{array}$ & $\begin{array}{c}\% \text { of plants } \\
\text { with flower buds }\end{array}$ & $\begin{array}{l}\text { No. of flower } \\
\text { buds per plant }\end{array}$ \\
\hline \multirow{8}{*}{1} & dark control & 38 & 100 & 2.9 \\
\hline & $\mathrm{R}$ & 37 & 81.1 & 1.1 \\
\hline & FR & 35 & 100 & 3.0 \\
\hline & $\mathrm{R} \rightarrow \mathrm{FR}$ & 34 & 91.2 & 1.5 \\
\hline & $\mathrm{R} \rightarrow \mathrm{FR} \rightarrow \mathrm{R}$ & 36 & 55.6 & 0.6 \\
\hline & $\mathrm{R} \rightarrow \mathrm{FR} \rightarrow \mathrm{R} \rightarrow \mathrm{FR}$ & 36 & 63.9 & 0.8 \\
\hline & $\mathrm{R} \rightarrow \mathrm{FR} \rightarrow \mathrm{R} \rightarrow \mathrm{FR} \rightarrow \mathrm{R}$ & 34 & 32.4 & 0.3 \\
\hline & $\mathrm{R} \rightarrow \mathrm{FR} \rightarrow \mathrm{R} \rightarrow \mathrm{FR} \rightarrow \mathrm{R} \rightarrow \mathrm{FR}$ & 34 & 76.5 & 0.8 \\
\hline \multirow{7}{*}{2} & FR & 35 & 85.5 & 1.1 \\
\hline & $\mathrm{R}$ & 38 & 84.2 & 1.3 \\
\hline & $\mathrm{FR} \rightarrow \mathrm{R}$ & 35 & 74.3 & 0.8 \\
\hline & $\mathrm{FR} \rightarrow \mathrm{R} \rightarrow \mathrm{FR}$ & 35 & 51.5 & 0.5 \\
\hline & $\mathrm{FR} \rightarrow \mathrm{R} \rightarrow \mathrm{FR} \rightarrow \mathrm{R}$ & 35 & 62.9 & 0.7 \\
\hline & $\mathrm{FR} \rightarrow \mathrm{R} \rightarrow \mathrm{FR} \rightarrow \mathrm{R} \rightarrow \mathrm{FR}$ & 35 & 2.9 & 0.0 \\
\hline & $\mathrm{FR} \rightarrow \mathrm{R} \rightarrow \mathrm{FR} \rightarrow \mathrm{R} \rightarrow \mathrm{FR} \rightarrow \mathrm{R}$ & 33 & 30.3 & 0.3 \\
\hline \multicolumn{5}{|c|}{$\begin{array}{l}\text { FR: } 10 \text {-second far-re } \\
\text { F: } 20 \text {-second red } 1 \\
\text { FR: } 2 \text {-minute far-red }\end{array}$} \\
\hline
\end{tabular}

Ten seconds of far-red given in the middle of 16-hour dark period had little effect on the flowering response, although such far-red radiant energy can partially reverse the inhibitory effect of red.

If 2 minutes of far-red was followed by a 20 second exposure to red, the flowering response was reduced, but when both red and far-red are given alternately some reversing effect of red is observable. That is, the rate of repromotion appears to increase with repetition of cycles.

Experiment 6. Plants were placed in darkness for 8 hours. At the close of the dark period red or far-red radiant energies of different intensities were given for various durations so as to make the total energy $180 \mathrm{kiloerg} / \mathrm{cm} .{ }^{2}$ or $1800 \mathrm{kiloerg} / \mathrm{cm} .{ }^{2}$ respectively. Immediately thereafter, plants were again placed in darkness for 16 hours.

Results are shown in Table 4. Both red and far-red inhibited flower initiation more vigorously when given at low intensities for long durations. 
Table 4. Influence of light intensities upon effectiveness of light-break.

Red or far red radiant energies of various intensities were inserted between 8 - and 16-hour dark period for various durations, so as to make the total energy 180 or $1800 \mathrm{kiloerg} / \mathrm{cm}^{2}$, respectively.

(Treated on April 25 and dissected on May 9, 1959)

\begin{tabular}{|c|c|c|c|c|c|}
\hline \multicolumn{3}{|c|}{ Light inserted } & \multirow{2}{*}{$\begin{array}{l}\text { No. of } \\
\text { plants } \\
\text { dissected }\end{array}$} & \multirow{2}{*}{$\begin{array}{c}\% \text { of } \\
\text { plants with } \\
\text { flower buds }\end{array}$} & \multirow{2}{*}{$\begin{array}{l}\text { No. of } \\
\text { flower buds } \\
\text { per plant }\end{array}$} \\
\hline Quality & Duration & $\begin{array}{l}\text { Intensity in } \\
\mathrm{erg} / \mathrm{cm} .^{2} / \mathrm{sec}\end{array}$ & & & \\
\hline $\mathrm{R}$ & $2^{\prime}$ & 1500 & 35 & 80.0 & 1.4 \\
\hline $\mathrm{R}$ & $5^{\prime}$ & 600 & 37 & 78.4 & 1.4 \\
\hline $\mathrm{R}$ & $30^{\prime}$ & 100 & 35 & 68.6 & 1.0 \\
\hline $\mathrm{R}$ & $2 \mathrm{~h}$ & 25 & 38 & 0 & 0 \\
\hline $\mathrm{R}$ & $4^{\mathrm{h}}$ & 12.5 & 37 & 0 & 0 \\
\hline $\mathrm{R}$ & $8 \mathrm{~h}$ & 6 & 34 & 2.9 & 0.0 \\
\hline FR & $2^{\prime}$ & 15000 & 34 & 100 & 2.7 \\
\hline FR & $5^{\prime}$ & 6000 & 32 & 100 & 2.7 \\
\hline FR & $30^{\prime}$ & 1000 & 37 & 45.9 & 0.5 \\
\hline FR & $2^{\mathrm{h}}$ & 250 & 37 & 37.8 & 0.4 \\
\hline FR & $4 \mathrm{~h}$ & 125 & 37 & 16.2 & 0.2 \\
\hline FR & $8^{h}$ & 63 & 38 & 13.2 & 0.1 \\
\hline \multicolumn{3}{|c|}{ dark control } & 38 & 100 & 4.0 \\
\hline \multicolumn{3}{|c|}{$32^{\mathrm{h}} \mathrm{R}\left(6 \mathrm{erg} / \mathrm{cm} .{ }^{2} / \mathrm{sec}.\right)$} & 34 & 2.9 & 0.0 \\
\hline \multicolumn{3}{|c|}{$32^{\mathrm{h}}$ FR $\left(63 \mathrm{erg} / \mathrm{cm} .{ }^{2} / \mathrm{sec}.\right)$} & 29 & 0 & 0 \\
\hline
\end{tabular}

\section{Discussion}

In Pharbitis seedlings a light-break with red radiant energy is effective only 8 to 12 hours after the beginning of the dark period. The process inducing flowering probably becomes light-sensitive at this time, and thereafter, the process becomes stable to the light.

A brief far-red irradiation given during the first 12 hours of the dark period also inhibits flower initiation of Pharbitis Nil. As had been reported previously ${ }^{15}$ ), far-red preceding the inductive dark period also inhibits flowering especially when the far-red irradiation lasts for 8 hours or more. The present experiments showed that the flower-inhibitory effect of far-red is at a maximum near the 8th hour of the dark period. The first process of the inductive dark period is believed to proceed under far-red irradiation $\left.{ }^{15,16,17}\right)$. Therefore, it is conceivable that, if the far-red irradiation is continued for 8 hours or more preceding the dark period, the first process of the inductive dark period proceeds under this light, and the process becomes sensitive to far-red, and subsequently heavy flower inhibition takes place.

Low-intensity light is also effective for light-break (cf. Experiment 6). Hitherto, an inhibitory effect of low-intensity light preceding the inductive dark period was considered due to the deficiency of photosynthate and was completely overcome by feeding sugar. Preliminary experiments, however, showed that the flower-inhibitory effect of low-intensity light preceding the dark period is not overcome by feeding sugar in Pharbitis plants (unpublished). Furthermore, as has been reported previously: 1) the first process of the inductive dark period can proceed under low-intensity 
light $\left.(10 \operatorname{lux})^{16,17}\right)$, 2) low-intensity light of less than 8 hours preceding the inductive dark period does not inhibit flower initiation if it contains little far-red, but that of 8 hours or more inhibits flowering $\left.{ }^{14-17}\right)$, 3) a brief red irradiation following the 8hour low-intensity light period (preceding the dark period) inhibits flower initiation ${ }^{17}$ ). Therefore, it seems probable that low-intensity light of long duration preceding the dark period has a light-break effect. That is, during the first 6-8 hours of the lowintensity light, the first process of the inductive dark period proceeds ${ }^{16,17}$ ) and the following low-intensity light period gives the light-break effect.

In Pharbitis seedlings flower inhibition caused by a red interruption in the middle of 16-hour dark period appears not to be reversed by the following far-red irradiation of 1 minute or more. The far-red radiant energy may reverse the flower-inhibitory effect of red to some extent, but the flower-inhibitory effect of far-red-the mechanism appears to differ from that of the red interruption-may exceed the reversing one. As shown in Experiment 5, if the duration of the far-red irradiation was shortened to 10 seconds, some reversing effect is apparent. The reversing effect of the far-red may exceed the inhibitory one in this case. On the other hand, if the duration of the red irradiation was shortened to 20 seconds, some reversing effect of red on the far-red response was observed.

Red radiant energy given at the 4 th hour of the dark period does not inhibit flower initiation, but far-red given at this time does so. The inhibitory effect of the latter can be reversed completely by a following red irradiation (cf. Experiment 2). The red-far-red antagonism is observed clearly in this case.

The flower-inhibitory effect of red and far-red radiant energy is assumed to be based on different mechanisms, although the antagonism between them exists in

Pharbitis seedlings. Nakayama reported that in Pharbitis seedlings no repromotive action of a far-red irradiation immediately following the red one was observed. In his experiments, the intensity of far-red was so high that the inhibitory effect of farred may have exceeded the reversing one.

In other short day plants, such as Xanthium, Biloxi soybean etc., far-red may have little effect on flowering when given in the middle of the dark period, and the reversing effect of far-red may be observed more clearly.

\section{Summary}

1) A red interruption was effective for flower inhibition only 8 to 12 hours after the beginning of the dark period irrespective of the duration of the dark period. A 5 -minute exposure to far-red $\left(15 \mathrm{kiloerg} / \mathrm{cm} .{ }^{2} / \mathrm{sec}\right.$.) given immediately following a 2minute red irradiation $\left(1500 \mathrm{erg} / \mathrm{cm}^{2} / \mathrm{sec}\right.$.) did not remove the inhibitory effect of red at any time during the dark period.

2) A brief far-red irradiation given during the first 12 hours of the dark period inhibited flower initiation. Maximum inhibition was obtained at the 8th hour. Two minutes of red following 5 minutes of far-red reversed the inhibitory effect of farred completely during the first 4 hours of the dark period, but had little effect at any other time.

3) The inhibitory effect of 1-minute red irradiation given in the middle of a 16-hour dark period was reversed to some extent by the following far-red irradiation, if the duration of the latter was shortened to some 10 seconds.

The inhibitory effect of 2-minute far-red irradiation given in the middle of a 16hour dark period was reversed to some extent by a following 20-second exposure to 
red.

4) The flower-inhibitory effect of red and far-red given at the 8th hour of a long dark period is stronger when given to the plant with low intensities for long durations than when given with high intensities for short durations.

Grateful acknowledgment is given to Prof. S. Imamura for his suggestion and criticisms.

\section{References}

1) Hamner, K. C., and Bonner, J., Bot. Gaz., 100: 388 (1938). 2) Harder, R., und Bode, O., Planta, 33: 469 (1943). $\quad$ 3) Salisbury, F. B., and Bonner, J., Plant Physiol., 31: 141 (1956). 4) Wareing, P. F., Physiol. Plantarum, 7: 157 (1954). 5) Bünsow, R., Z. Bot., 41: 257 (1953). 6) Melchers, G., Z. Naturforsch., 11 b: 544 (1956). 7) Schwabe, W. W., Physiol. Plantarum, 8: 263 (1955). 8) Takimoto, A., and Ikeda, K., Bot. Mag. Tokyo, 73: 91 (1960). 9) Parker, M. W., Hendricks, S. B., Borthwick, H. A., and Scully, N. J., Bot. Gaz., 108: 1 (1946). 10) Borthwick, H. A., Hendricks, S. B., and Parker. M. W., Bot. Gaz., 110: 103 (1948). 11) —, and - Proc. Natl. Acad. Sci., 38: 929 (1952). 12) Downs, R. J., Plant Physiol., 31: 279 (1956). 13) Nakayama, S., The Science Report of the Tohoku Univ., Sendai, S 4, 24: 137 (1958). 14) Takimoto, A., and Ikeda, K., Bot. Mag. Tokyo, 72: 137 (1959). 15) and - , ibid. 72: $181(1959) . \quad 16)-$, and - , ibid. $72: 388(1959) .17)-$, and —, ibid. 73: 175 (1960).

\section{摘 要}

滝本 敦・池田勝彦：アサガオの花芽形成を支配する光条件について VII：光中断

1）暗期の長さに関係なく, 赤色光による光中断は暗期開始後 8〜12 時間目に特いてのみ有効である. 光中断として 2 分間赤色光 $\left(1500 \mathrm{erg} / \mathrm{cm} .{ }^{2} / \mathrm{sec}\right.$. $)$ を与穴た直後に 5 分間近赤外光 $\left(15 \mathrm{kiloerg} / \mathrm{cm} .{ }^{2} / \mathrm{sec}.\right)$ を照射してる，前者による花芽形成抑制効果は消却されない。

2) 暗期の長さに関係なく近赤外光による光中断は暗期開始後 0 12 時間目に招いてのみ有効であり, 8 時間目で最もいちじるしい花芽形成抑制効果を示す. 5 分間の近赤外光照射に続いて 2 分間赤色光を与 党ると, 暗期の初期 $0 \sim 4$ 時間目に招いては, 前者による花芽形成抑制效果が完全に消却されるが, 喑期 の他の時期に和いては，ほとんどその影響が見られない。

3） 16 時間暗期の中央で 1 分間の赤色光と 10 秒間の近赤外光を交互に数回与㝋ると, 最後の照射光が 赤色光の場合上りも, 近赤外光の場合の方が高い開花反応を示す. これに反して, 2 分間の近赤外光と 20 秒間の赤色光を交互に与壳た場合には, 最後に与充た光が近赤外光の場合よりも赤色光の場合の方が高い 開花反応を示す.

赤色光と近赤外光の拮抗作用はあるが，各々が異なった機棈で花芽形成を抑制するため，拮抗作用がな いように見党る場合が多いものと考觉られる.

4) 赤色光, 近赤外光共に強い光を短時間照射するよりも, 弱い光を長時間照射する方が強い花芽形成 抑制作用を示す.（京都大学農学部応用植物学研究室） 